\title{
More Than What Courts Do: Jurisprudence, Decision, and Dignity-In Brief Encounters and Global Affairs
}

\author{
Robert D. Sloane $e^{\dagger}$ \\ Any law that uplifts human personality is just. \\ Any law that degrades human personality is unjust. \\ - Martin Luther King, Jr. ${ }^{1}$
}

\begin{abstract}
Describing Baruch de Spinoza, Matthew Stewart wrote:
Some philosophers merely argue their philosophies. When they finish their disputations, they hang up the tools of their trade, go home, and indulge in the well-earned pleasures of private life. Other philosophers live their philosophies. They treat as useless any philosophy that does not determine the manner in which they spend their days, and they consider pointless any part of life that has no philosophy in it. They never go home. ${ }^{2}$
\end{abstract}

The same, perhaps, may be said of jurisprudence. If so, then, like Spinoza, W. Michael Reisman, this conference's honoree, falls clearly into the latter category. His jurisprudence informs his work and his life-as a scholar, teacher, practitioner, friend, and public citizen. Having been privileged to know or work with him in most of these capacities, I have often been struck by how the methods and injunctions of the New Haven School shape his personal, no less than professional, character traits. He exhibits an acute sensitivity to context, cultivates a studied habit of disengaging from biases, and always reflects on arguments before replying: he responds rather than reacts. Not coincidentally, the New Haven School encourages these traits, and no living scholar or practitioner is identified more closely with it than Reisman. Below, beyond describing some precepts of the School, I want to focus on a few areas in which Reisman made signature contributions to its jurisprudence of realistic idealism.

In many introductory jurisprudence courses, students learn that the topic asks two fundamental questions: first, what distinguishes legal norms from other norms, for example, those of etiquette (theories of law); and second, how do, or should, judges decide hard cases, that is, those in which the law does not clearly dictate a single right answer (theories of adjudication)? For the international lawyer, it should be immediately apparent that the utility of both questions is profoundly limited. Consider their respective assumptions: first, that qualitative features of certain norms (pedigree or other criteria of

$\dagger \quad$ Associate Professor of Law, Boston University School of Law.

1. MARTIN LUther King, JR., LeTter FROM Birmingham CITY JAIL (1963), reprinted in A Testament OF Hope: The Essential WRitings and SPEeches of MARTIN LUTHER King JR. 289, 293 (James Melvin Washington ed., 1986).

2. Matthew Stewart, THE COURTIER AND THE Heretic 54 (2006). 
legal validity) do distinguish genuine legal norms from other sorts of norms; and second, that judges constitute the paradigmatic, if not exclusive, appliers of law.

In the notoriously decentralized and often unstable international legal system, neither assumption necessarily holds. International lawyers must ascertain the extent to which a host of putative governing norms (whether traditionally deemed legal or not) affect the decisions of diverse, politically relevant actors, ${ }^{3}$ meaning those with effective power in equally diverse contexts: from domestic courts to sui generis international tribunals to diplomatic fora to "informal channels"4 that many might not even recognize as jurisgenerative. And despite the proliferation of international tribunals, ${ }^{\xi}$ it is still true that comparatively little international law is made, interpreted, or enforced by courts-a fortiori if, by courts, we mean domestic courts within a hierarchical legal system with reliable and effective enforcement powers.

That is why Reisman has repeatedly stressed that Holmes's aphorismthat "[t]he prophecies of what the courts will do ... are what I mean by the law" -is so misguided in international law. ${ }^{7}$ Outside the few contexts in which authority (legitimacy) and control (power) converge in a tribunal of some sort, the international lawyer would be professionally derelict to make decisions or advise clients based on a jurisprudence conceived in terms of a hierarchy of courts applying appropriately pedigreed norms. International lawyers, in particular, but indeed all lawyers, need a methodology that can capture the myriad facts and factors that influence the processes of decision in different legal and political contexts.

Most jurisprudential scholarship regrettably offers them little help. ${ }^{8}$ In his "Short Guide for the Perplexed" to the "Hart-Dworkin" debate, ${ }^{9}$ Scott Shapiro notes that this debate has dominated jurisprudential scholarship in the United States for more than forty years, since Ronald Dworkin published The Model of Rules in 1967, critiquing H.L.A. Hart's influential reformulation of legal positivism. ${ }^{10}$ Remarkably, however, and all the more so because Hart devoted a chapter to international law in The Concept of Law, ${ }^{11}$ one searches the literature on the Hart-Dworkin debate in vain for further attention to international law. Of course, international lawyers have engaged in their own vibrant debate about the nature of international law, generating sundry

3. Myres S. McDougal et al., Theories About International Law: Prologue to a Configurative Jurisprudence, 8 VA. J. INT'L L. 188, 189-92 (1968).

4. W. Michael Reisman, International Incidents: Introduction to a New Genre in the Study of International Law, in INTERNATIONAL INCIDENTS 3, 13 (W. Michael Reisman \& Andrew R. Willard eds., 1988).

5. See Thomas Buergenthal, Proliferation of International Courts and Tribunals: Is It Good or Bad?, 14 LEIDEN J. INT'L L. 267, 268-69 (2001).

6. Oliver Wendell Holmes, Jr., The Path of the Law, 10 HARV. L. REV. 457, 461 (1897).

7. See, e.g., Reisman, supra note 4, at 10-11.

8. Jeremy Waldron's work stands out as an exception. E.g., Jeremy Waldron, The Rule of International Law, 30 HARV. J.L. \& PUB. POL'Y 15 (2006); see also JOHN FINNIS, NATURAL LAW AND NATURAL RIGHTS 238-45 (1980) (conceptualizing customary intemational law).

9. Scott J. Shapiro, The "Hart-Dworkin" Debate: A Short Guide for the Perplexed, in RONALD DWORKIN 22 (Arthur Ripstein ed., 2007).

10. Ronald M. Dworkin, The Model of Rules, 35 U. CHI. L. REV. 14 (1967)

11. H.L.A. HART, THE CONCEPT OF LAW 213-37 (2d ed. 1994). 
jurisprudential schools analogous to those in the domestic arena. ${ }^{12}$ But most mainstream theories of law still tend to beg the question of international law's status by presupposing the apparatus of a functional state as the paradigm of real law.

This is unfortunate and ironic. Hart aspired to elucidate the concept of law, not of any particular legal system. ${ }^{13} \mathrm{He}$ concluded that international law, while perhaps not to be derided in Austinian terms as mere "positive morality," 14 lacks the secondary rules that characterize all mature legal systems. ${ }^{15}$ Yet perspective, as the New Haven School insists, is crucial. Within a statist paradigm, the conclusion that international law lacks what Hart called secondary rules is virtually tautological. Disengaged from those tacit assumptions, I believe it is clear that international law does have secondary rules-or their rough analogue, what the New Haven School denotes constitutive processes, viz., decisions about how decisions will be made, where, and by whom. It is just that those processes bear scant resemblance to the formal symbols and institutions of law in states. Their complexity, dynamism, and sensitivity to power also render the idea of capturing them in a monolithic rule of recognition even more fanciful than in the domestic sphere. ${ }^{16}$ If Hart therefore erred in denying that international law is genuine law, then it should stand as an objection to any theory of law writ large that it cannot comprehend the international legal system or offer international lawyers practical guidance. For jurisprudence is not, or should not be, a pejoratively academic enterprise. In fact, international lawyers, even more than their domestic counterparts, have a deeply practical need to understand how the legal system in which they operate actually functions. Only then can they responsibly and accurately determine whether and how they might influence it.

To those familiar with his work, it will come as no surprise that Reisman, like his intellectual forebears Myres S. McDougal and Harold D. Lasswell, always took a dim view of positivism, critiquing it on descriptive and normative grounds. ${ }^{17}$ In part, this is because its explanatory force is so manifestly weak in the international sphere. In part, it is because some early and unsophisticated forms of legal positivism, at bottom, mistakenly equate law with naked power. But it is also, in part, because positivism purports to be purely descriptive. ${ }^{18}$ Like the American legal realists, whom the New Haven School critiqued but upon whose insights it simultaneously built, ${ }^{19}$ Reisman regards jurisprudence as inescapably-and appropriately-normative. Pretense to a value-free jurisprudence at best obscures normative goals. In

12. See Harold Hongju Koh, Transnational Legal Process, 75 NEB. L. REv. 181, 187-90 (1996).

13. HART, supra note 11 , at 239-40.

14. John AUSTIN, The Province of JURISPRUdence Determined (David Campbell \& Philip Thomas eds., Dartmouth Publ'g 1998) (1832).

15. See HART, supra note 11, at 236-37.

16. Cf. Dworkin, supra note 10, at $41-42$ (analogous critique in the domestic legal sphere).

17. See generally McDougal et al., supra note 3, at 243-60.

18. See id. at 247.

19. W. Michael Reisman, Theory About Law: Jurisprudence for a Free Society, 108 YALE 
fact, if the New Haven School has a birth date, it is the 1943 publication of Legal Education and Public Policy: Professional Training in the Public Interest, in which McDougal and Lasswell argued in relevant part:

Even those who still insist that policy is no proper concern of a law school tacitly
advocate a policy, unconsciously assuming that the ultimate function of law is to
maintain existing social institutions in a sort of timeless statu quo [sic]; what they ask is
that their policy be smuggled in, without insight or responsibility.

Indeed, McDougal and Lasswell conceptually linked the pretense to a policyneutral legal education to the "outburst of racialism in [Nazi] Germany,... one of several profound recessions from the ideal of deference for the dignity and worth of the individual." ${ }^{21}$ From the outset, they therefore insisted on the indispensability of goal clarification, or the identification of preferred policies-a project unified by the moral postulate that law's ultimate goal should be to promote human dignity. Only after clarifying the policies to be pursued can lawyers responsibly perform their quintessential task: to make, or help others to make, decisions. And the continuous process of authoritative and controlling decision is, in the New Haven School's view, law itself.

This may initially seem counterintuitive. In liberal democracies, lawyers grow accustomed to conceptualizing decisionmaking as a function that follows, rather than precedes, identification of law. But law, like everything else, is in a constant state of flux. The decisions of judges, executive officials, administrative officers, and other elites-those who qualify as politically relevant actors in liberal democracies-tend to be far more predictable than those made in the international legal system because of the congruence of expectations of authority and control in a well-ordered state. Still, it is the process of authoritative and controlling decision about the distribution of values that constitutes law in the sense that matters to clients. That is why Reisman often stresses that to be truly effective, lawyers must distinguish a legal system's "myth system" from its "operational code." 22 As he wrote in one characteristic exposition:

\footnotetext{
Whatever you may mean by law, [clients] have a practical interest in how things are done in a certain setting and by law they mean those expectations shared by relevant members of the group about the right way of doing things, expectations taken seriously enough by group members so that they will probably be sustained by some individual or group effort. ${ }^{23}$
}

Analytically, Reisman and his colleagues therefore conceptualized lawmaking, or norm prescription, in terms of three coordinate communicative dimensions: (1) policy content, the extent to which a norm communicates a directive or prohibition: "thou shalt" or "thou shalt not"; (2) authority signal, the extent to which, empirically, the processes generating that norm and the symbols attached to it convey a sense of legitimacy or propriety to the

20. Harold D. Lasswell \& Myres S. McDougal, Legal Education and Public Policy: Professional Training in the Public Interest, 52 YALE L.J. 203, 207 (1943).

21. Id.

22. W. Michael ReISMAN, Folded LIES: BRIBERY, CRUSADES, AND REFORMS 16 (1979).

23. W. Michael Reisman, Law from the Policy Perspective, in INTERnational Law EsSays 1, 2 (Myres S. McDougal \& W. Michael Reisman eds., 1981). 
normative communication's recipients; and (3) control intention, the extent to which those recipients expect that those with effective power will invest sufficient resources to make the norm effective-in common parlance, to enforce it. ${ }^{24}$ All norms vary in clarity or strength along these dimensions. By methodically inquiring into each, the lawyer will be able to advise clients and shape the law far more effectively than by focusing solely on the familiar epistemic units of state law: statutes, administrative rules, appellate decisions, and other sources. ${ }^{25}$

Of course, in a well-ordered legal system like that of the United States, lawyers at times justifiably assume that authority and control will converge in identifiable institutions, especially courts. That is why appellate decisions generally offer a reliable prophecy of "what the courts will do in fact." Given the authority of courts in the United States and their reliable ability to enforce their decisions with state coercion, it is also why the prophecies of what the courts will do matter so much to U.S. clients. Yet it would be a manifestly catastrophic mistake to transpose Holmes's maxim to, say, nineteenth-century Venezuela, in which the formal trappings of a legal system-replete with jurists, courts, legislators, executive agents, and so forth-existed but in fact served as a veneer for caudillismo (de facto rule by a "strong man or Boss to whom subordinates owe personal rather than formal authority"). ${ }^{27}$ Still, many lawyers assume, consciously or not, that Holmes's vision can be transposed to the international legal system: small wonder that they conclude, with Austin, that there is no international law "properly socalled." To be effective in the international system, lawyers must scrutinize unfamiliar epistemic units, well beyond case law and texts. They must appreciate how the social processes to which international law is attached work, viz., who actually makes authoritative and controlling decisionswhere, when, and how.

Ironically, many critique the New Haven School as impracticable-too abstruse to be useful to practitioners. ${ }^{28}$ Nothing could be further from the truth, and Reisman's work, as a scholar and practitioner, is living proof. The School's methodology is not easy. In its quest for informed decision in the service of clear goals, it seeks comprehensively to map and scrutinize the factors, which, within any legal system, will be genuinely enlightening. It has developed methodical modes of inquiry in this regard, drawn from the social sciences, which seem almost Aristotelian in their precision and categories:

24. See generally W. Michael Reisman, International Lawmaking: A Process of Communication, The Harold D. Lasswell Memorial Lecture (Apr. 24, 1981), in 75 AM. SOC'Y INT'L L. Proc. 101 (1981).

25. Reisman, supra note 4, at 5-8.

26. Id. at 9; see also Holmes, supra note 6, at 461 .

27. W. Michael Reisman, Book Review, 29 AM. J. CoMP. L. 727, 727-28 (1981) (reviewing Rogelio Pérez Perdomo, El formalismo juridico y sus funciones Sociales en el Siglo XiX VENEZOLANO (1978)) (describing the coexistence of legal formalism and the operational code of caudillismo in nineteenth-century Venezuela). Roscoe Pound's sociological jurisprudence and, in particular, his distinction between "law on the books" and "law in action" supplies an influential antecedent of this distinction. Roscoe Pound, Law in Books and Law in Action, 44 AM. L. REV. 12 (1910).

28. E.g., Oscar Schachter, McDougal's Jurisprudence: Utility, Influence, Controversy, 79 AM. SOC'Y INT'L L. PROC. 266, 268 (1985). 
four intellectual tasks, ${ }^{29}$ seven dimensions of the social process, ${ }^{30}$ seven decision functions, ${ }^{31}$ and eight values. ${ }^{32}$ Yet this is one reason why the School, for all its apparent complexity, has proven so durable and attractive, not only to U.S. lawyers, but to generations of foreign students. It strives to identify and map the factors that lawyers would ideally know before advising others about, making, or appraising decisions in any legal environment: from the microlegal system governing "Looking, Staring, and Glaring,"33 to domestic legal systems of varying levels of stability and order, to the dynamic and often disorganized processes of international law.

One of Reisman's signature contributions to the New Haven School lies in his ability to expound its methods succinctly-to show, despite its facial complexity, how practical it proves. ${ }^{34}$ Consider one example: SecretaryGeneral Ban Ki-moon asks you to advise the United Nations on how best to restore a degree of order sufficient for the supply of humanitarian aid to Somalia's people to resume. ${ }^{35}$ How, as a lawyer, would you approach this problem? Reliance on text, precedents, and logical operations performed on traditional legal sources may make good sense in judicial or arbitral fora: contrary to a common misconception, the New Haven School jurist would not counsel, for example, the transnational business lawyer in an arbitration to engage in an "endless quest for shared expectations, value preferences and power relations on a global scale." ${ }^{36}$ In that context, familiar lawyerly tasks would be contextually appropriate, and insofar as traditional legal materials (texts, precedents, etc.) may be expected to be authoritative and controlling in context, the New Haven School jurist would be as likely to rely upon them as any other. But often the international lawyer's tasks defy resort to traditional methods and sources, which at best reveal the myth system rather than the operational code of a legal system.

In the context of seeking to effect the resumption of humanitarian aid in Somalia, formal legal sources alone would be manifestly inadequate to the task. This is not to say that they don't matter; only that their contextual relevance differs immensely. They may supply information about normative trends or preferred policy outcomes. But textual reliance alone would be absurd. To the New Haven School jurist, however, it would be equally mistaken to characterize the situation in Somalia as legal anarchy. Where a

29. Clarification of perspective, selection of appropriate focal lenses, mapping of community processes, and deliberation culminating in choice-itself a process subdivided into five steps: goal clarification, trend analysis, factor analysis, predictions, and invention of alternatives. Michael Reisman, 1995 Seibenthaler Lecture, A Jurisprudence from the Perspective of the "Political Superior," 23 N. KY. L. REV. 605, 613-20 (1996).

30. Participants, perspectives, situations, bases of power, strategies, outcomes, and effects. Reisman, supra note 23 , at $4,13$. Id. at 4.

31. Intelligence, promotion, prescription, invocation, application, termination, and appraisal.

32. Power, enlightenment, wealth, well-being, skill, affection, respect, and rectitude. Myres S. McDougal \& Harold D. Lasswell, The Identification and Appraisal of Diverse Systems of Public Order, 53 AM. J. INT'L L. 1, 12-13 (1959).

33. W. Michael Reisman, LaW in BRIEF ENCOUNTERS 21 (1999).

34. See, e.g., Reisman, supra note 4, at 3; Reisman, supra note 23, at 1; W. Michael Reisman, The View from the New Haven School of International Law, 86 AM. SOC'Y INT'L L. PROC. 118 (1992).

35. I have adapted this example from Reisman's 2007 Hague Academy lectures.

36. Schachter, supra note 28 , at 268. 
community exists, so does law. The legal systems (plural) within the politically anarchic state of Somalia would be quite complex and variable. But the careful jurist would find that diverse processes of authoritative and controlling decision indeed exist, overlap, and interact throughout Somalia.

So how should the international lawyer plausibly think about SecretaryGeneral Ban's assignment in Somalia? With whom should she deal? To be effective, she must first be able to identify all the participants, understand their roles, appreciate their modes of decision, and comprehend their relationships to one another. She would likely find the local scene controlled by a complex blend of private armies, clans, criminal gangs, multinational corporations seeking to protect their investments, agents of foreign governments trying to promote political or economic interests, religious leaders with authority among sectors of the local populace, nongovernmental organizations trying to ameliorate sickness and hunger, and transnational terrorist networks seeking to establish a safe haven. She would need to identify the relevant loci of authority and control that together would determine the likely efficacy of efforts to instantiate new norms-in this case, norms that might enable aid supplies to resume. But where, as in Somalia, effective institutions do not exist, she would also need to consider how to craft legal arrangements so that either (1) politically relevant actors perceive them as in their self-interest, or (2) external actors may be mobilized, if necessary, to deploy coercionwhich, it should be stressed, need not mean violence; it includes diplomatic, ideological, and economic, as well military, means.

Beyond mapping the decision process for purposes of prediction and efficacy in a range of legal settings, the New Haven School seeks to enhance that process-to empower individuals to participate effectively in it and to promote the optimal shaping and sharing of values. This makes its jurisprudence particularly attractive to the disenfranchised. It supplies them with the tools to become effective participants in the legal process-and not simply politically inferiors, searching for rules to obey. Unlike positivism, the New Haven School encourages lawyers to adopt the perspective of the political superior, a perspective particularly well suited to international law. The instability, decentralization, and diversity of the international system, while often lamentable, generates ample opportunities for lawyers to shape and creatively influence international law. The School seeks to identify those opportunities as a means to empower lawyers "to influence the way social choices are continuously made about the production and distribution of resources, including considerations about the ways that decisions should be made about those things." 37

Because, in international law, the convergence of authority and control is often the exception rather than the rule, the practice of international law requires, as Reisman has often said, the cultivation of realism, especially about the role of power. ${ }^{38}$ Yet the extent to which "power trumps" in many areas of international law must not, as he has been equally quick to insist, lead lawyers to lose their sense of indignation at injustice and violations of human 
dignity. A parochial focus on power, without recognizing that all power is relative, and without the creative formulation and pursuit of goals, culminates in nihilism-or in a sterile intellectualism that denies the efficacy of international law without appreciating the extent to which this kind of cynicism is a self-fulfilling prophecy. Understanding power's role in international law does not mean apologizing for it:

That, intermational law notwithstanding, a large state will intervene in the affairs of a smaller state if it deems its own security threatened does not mean that it is right for it to do so. ... It does mean that people in the smaller or larger state who are trying to develop a realistic set of matter-of-fact expectations ... will be wise to put this possibility into their reckoning. ${ }^{39}$

How, then, can international lawyers ultimately be effective in a system in which myth system and operational code frequently diverge? The answer lies in another of Reisman's key contributions to the New Haven School: If every legal system can best be understood in terms of a continuous flow of normative communications with varying levels of authority and control, then the more authoritative the communication, the less it will need to rely on coercion; conversely, the less authoritative the communication, the more law must rely on coercion. That is why well-ordered legal systems with authoritative formal institutions seldom need to rely on overt coercion to preserve the law or compel enforcement. Effective institutions would be preferable in the international system as well. Yet until international law reaches that point (and that day is surely not near), effective international lawyering requires crafting arrangements such that sufficient numbers of politically relevant participants see those arrangements as in their selfinterest. That, in brief, is what a jurisprudence of realistic idealism in international law requires. The legacy of Reisman's jurisprudence of realistic idealism emerges not only in his scholarship and practice, but in the many students and colleagues, including those in attendance today, whose intellectual and professional lives he has indelibly marked. 